\title{
VOLTAMMETRIC QUANTIFICATION OF A NONSTEROIDAL ANTI-INFLAMMATORY AGENT DIFLUNISAL BASED ON THE ENHANCEMENT EFFECT OF CATIONIC SURFACTANT ON BORON-DOPED DIAMOND ELECTRODE
}

\author{
Ertuğrul Keskin $^{1 *}$, Shabnam Allahverdiyeva², Amer Alali³, Yavuz Yardım ${ }^{3 *}$ \\ ${ }^{1}$ Adlyaman University, Faculty of Pharmacy, Department of Analytical Chemistry, 02040 Adiyaman, Turkey \\ ${ }^{2}$ Van Yüzüncü Yll University, Faculty of Science, Department of Biochemistry, 65080 Van, Turkey \\ ${ }^{3}$ Van Yüzüncü Yll University, Faculty of Pharmacy, Department of Analytical Chemistry, 65080 Van, Turkey \\ keskinertugrul@gmail.com; yavuzyardim2002@yahoo.com
}

\begin{abstract}
The present work describes a simple, fast and inexpensive voltammetric method for diflunisal measurement using a non-modified boron-doped diamond (BDD) electrode. The oxidation of the agent was irreversible and was a diffusion-controlled process. The sensitivity of the square wave voltammetric measurements were significantly improved when the cationic surfactant, cetyltrimethylammonium bromide (CTAB), was present in the supporting electrolyte solution. Using the square-wave mode, a linear response was obtained for diflunisal quantification in a $0.1 \mathrm{~mol} \mathrm{l}^{-1}$ phosphate buffer solution $(\mathrm{pH} 2.5)$ containing $5 \cdot 10^{-5} \mathrm{~mol} \mathrm{l}^{-1} \mathrm{CTAB}$ at $+1.07 \mathrm{~V}$ (vs. $\mathrm{Ag} / \mathrm{AgCl}$ ) (after $30 \mathrm{~s}$ accumulation under open-circuit conditions). Linearity was found for 0.05 to $2.0 \mathrm{gg} \mathrm{ml}^{-1}\left(2.0 \cdot 10^{-7}-8.0 \cdot 10^{-6} \mathrm{~mol} \mathrm{l}^{-1}\right)$ with a detection limit of $0.013 \mu \mathrm{g} \mathrm{ml}^{-1}\left(5.2 \cdot 10^{-8} \mathrm{~mol} \mathrm{l}^{-1}\right)$. The developed approach could be used for the quantification of diflunisal in pharmaceutical formulations.
\end{abstract}

Keywords: diflunisal; boron-doped diamond electrode; voltammetry; cationic surfactant; pharmaceutical formulation

\section{ВОЛТАМЕТРИСКО ОПРЕДЕЛУВАҢЕ НА НЕСТЕРОИДНИОТ АНТИИНФЛАМАТОРЕН ЛЕК ДИФЛУНИЗАЛ БАЗИРАНО НА ЕФЕКТОТ НА ЗГОЛЕМУВАЫЕ НА КАТЈОНСКИ СУРФАКТАНТ СО БОР МОДИФИКУВАНА ДИЈАМАНТСКА ЕЛЕКТРОДА}

Во овој труд е опишана едноставна, брза и евтина волтаметриска метода за определување дифлунизал со примена на дијамантска електрода модификувана со бор (BDD). Оксидацијата на аналитот е иреверзибилна реакција што се случува во процес контролиран од дифузија. Осетливоста на квадратно-брановата волтаметриска метода е значително подобра во присуство на катјонскиот сурфактант цетилтриметиламониумбромид (СТАВ). Со примена на квадратнобрановата волтаметрија, линеарен одговор помеѓу измерената струја и дифлунизал е детектиран во фосфатен пуфер со концентрација од $0,1 \mathrm{mo} / 1$ и $\mathrm{pH} 2,5$, во присуство на $5 \cdot 10^{-5} \mathrm{~mol}^{-1} \mathrm{CTAB}$, а по 30 секунди акумулација при отворено електрично коло на $+1,07 \mathrm{~V}$ (во однос на $\mathrm{Ag} / \mathrm{AgCl}$ ). Линеарен опсег помеѓу измерените пик-струи и концентрацијата на аналитот постои во границите од 0,05 до $2,0 \mu \mathrm{g} \mathrm{ml}^{-1}\left(2,0 \cdot 10^{-7}-8,0 \cdot 10^{-6} \mathrm{~mol} \mathrm{l}^{-1}\right)$, со пресметаната граница на детекција од $0,013 \mu \mathrm{g}$ $\mathrm{ml}^{-1}\left(5.2 \cdot 10^{-8} \mathrm{~mol} \mathrm{l}^{-1}\right)$. Опишаната волтаметриска метода може да се употреби за квантитативно определување на дифлунизал во фармацевтски формулации.

Клучни зборови: дифлунизал; со бор-модификувана дијамантска електрода; волтаметрија; катјонски сурфактант; фармацевтски формулации 


\section{INTRODUCTION}

Non-steroidal anti-inflammatory drugs (NSAIDs) are currently the most prescribed drugs for the treatment of mild to moderate pain [1]. The mechanism of relieving pain with these drugs occurs mainly by inhibiting the cyclooxygenase enzyme and thus stopping the production of prostaglandins [2]. Diflunisal (abbreviated as DIF, namely: 2',4'-difluoro-4-hydroxybiphenyl-3-carboxylic acid shown in Figure 1 is a difluorophenyl derivative of salicylic acid within the NSAID class of drugs with long-term analgesic activity [3]. It is mostly prescribed to relieve pain developing postoperative to dental and surgical operations [4].

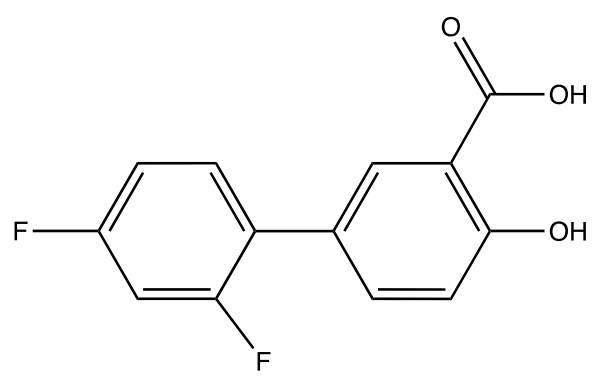

Fig. 1. Chemical structure of diflunisal

To date, various analytical methodologies were developed for the determination of DIF alone or in combination with other drugs in pharmaceutical formulations, biological fluids, and wastewater. The majority of these analyses are based on spectrophotometry [5], spectrofluorimetry [6, 7], liquid chromatography (LC) [8-12], and capillary electrophoresis [13, 14] methods. Although some of these methods offer good selectivity and sensitivity, they involve disadvantages such as expensive instrumentation, excessive chemical consumption, and intense pretreatment procedures. Only two electrochemical analysis methods have been proposed for DIF analysis $[15,16]$. In the first study, the electrochemical behavior of DIF and its quantitative determination was performed by using the reduction peak of DIF on a static mercury drop electrode (SMDE). In another study using SMDE, the electrochemical reduction behavior of DIF and its chlorinated analogs were investigated in nonaqueous media [17]. This paper mostly focuses on the reduction mechanism of DIF rather than its quantitative analysis. Although DIF is a compound containing an oxidizable functional group in its chemical structure, there is only one study in the scientific literature that conducted quantitative DIF analysis using this oxidation peak [16]. In this study, a carbon paste electrode modified with montmorillonite-Ca was used, and a good level of sensitivity was obtained. Despite the good sensitivity of the method, the modification of the electrode has disadvantages such as being a time-consuming step, requiring expensive chemical use, and the electrodes providing poorly reproducible responses. Due to the fact that DIF is a widely used drug and considering its clinical importance, a more practical methodology is needed. No methodology for the electrochemical analysis of DIF in the presence of a surfactant was found in the scientific database which uses a BDD electrode that is simple, fast, economical, and also offers good sensitivity and selectivity.

Electrochemical analysis methods differ from other analytical methods with their speed, ease of application, reliability, and simplicity [18, 19]. In addition, they offer considerable sensitivity and selectivity depending on the type of working electrode and the technique used [20, 21]. Undoubtedly another outstanding feature is that they clarify the redox behavior of the related species $[22,23]$. It is a known fact that the type of electrode used in the analyses performed with these methods, the pretreatment procedures, and the modification steps applied to the electrode play great roles in the electrochemical behavior of the analyte [24-26].

A boron-doped diamond (BDD) electrode is a carbonaceous electrode material that offers distinctive features such as a wide working window (both cathodic and anodic direction), low ground current, low signal-noise ratio, operation in corrosive environments and reproducible responses to electrochemical analyses. [27]. Electroactive species that cannot be examined with conventional metal and other carbon electrodes can be analyzed with the wide working window of this electrode material [28]. BDD electrodes permit limited modification with modifying agents compared to electrode materials such as glassy carbon. The main reason for this is the low adsorption of both the analyte and the modifying agent on the surface of the BDD electrode material [29]. However, the sensitivity of this electrode can be increased with some pretreatment steps applied to the electrode material prior to analysis in the presence of various surfactants [30].

The electrochemical pretreatment step is one of the most widely used techniques to increase the sensitivity of the BDD electrode. This procedure applies a certain potential to the BDD electrode in an anodic or cathodic direction for a certain period of time. To improve the sensitivity, these pretreat- 
ment procedures applied to the electrode can be performed anodically or cathodically, anodically followed by cathodically, or vice versa. Many electrochemical approaches based on BDD electrodes have increased electrode sensitivity using such steps $[31,32]$.

In electrochemical analysis, the presence of an amphiphilic surfactant is known to increase both the selectivity and sensitivity of some electroactive species [33]. This phenomenon occurs as a result of the increased solubility of the electroactive species and the variation in electrodeelectrolyte interface characteristics in the surfactant environment. This synergistic effect leads to better adsorption of the related species on the electrode surface and accelerates the charge transfer between the electrode and the electrolyte [34]. Recently, our research group focused on studies that highlight this role of surfactants in electrochemical analysis $[26,35,36]$.

This article aims to develop an approach to the practical use of the BDD electrode for the detection and quantitative analysis of DIF in the presence of cetyltrimethylammonium bromide (CTAB). As far as we know, no approach is found in the literature for DIF analysis that uses a BDD electrode in surfactant media. The main motivation for this study is to offer a good alternative method for DIF analysis that is comparable with other analytical methods in terms of sensitivity, selectivity and practical use. In optimized conditions, the applicability of the method was successfully illustrated for commercial pharmaceutical samples.

\section{EXPERIMENTAL}

\subsection{Chemicals and solutions}

DIF standard (ReagentPlus ${ }^{\circledR}, \geq 99.37 \%$ ) was purchased from ChemScene LLC (USA) and used as received. The stock standard solutions of $1 \mathrm{mg}$ $\mathrm{ml}^{-1}$ of DIF were prepared by dissolving in ethanol, and they were stored in a volumetric flask in a refrigerator at $4-6{ }^{\circ} \mathrm{C}$ in order to avoid degradation when not in use. Analytical-grade reagents and water purified in a Millipore Milli-Q system (Millipore, resistivity $\geq 18.2 \mathrm{M} \Omega \mathrm{cm}$ ) were used for the preparation of Britton-Robinson (BR, $0.1 \mathrm{~mol} \mathrm{l}^{-1}$, $\mathrm{pH} 2-10)$ phosphate buffer solution (PBS, $0.1 \mathrm{~mol}$ $\left.\mathrm{l}^{-1}, \mathrm{pH} 2.5\right)$ and $\mathrm{HNO}_{3}\left(0.1 \mathrm{~mol} \mathrm{l}^{-1}\right)$. The cationic surfactant $(\mathrm{CTAB})$ solution was prepared by dissolving the required amount of solid in a water/methanol mixture $(9: 1, \mathrm{v} / \mathrm{v})$. The working and calibration solutions of DIF were prepared from the stock solution before use by appropriate dilu- tion with the selected supporting electrolyte. All analysis and voltammetric measurements were carried out under laboratory conditions.

\subsection{Apparatus and measurements}

All CV and SW recordings were conducted with a potentiostat/galvanostat analyzer ( $\mu$ Autolab type III, Metrohm Autolab B.V., The Netherlands) driven by GPES (General Purpose Electrochemical Software) software version 4.9 in connection with a personal computer. All SW recordings were smoothed using a Savicky and Golay algorithm and baseline-corrected by the moving average algorithm filtering technique (peak width of $0.01 \mathrm{~V}$ ). Electrochemical measurements were performed using an electrochemical cell setup consisting of three electrodes including a BDD working electrode (diameter of $3 \mathrm{~mm}$, boron doping level of 1000 ppm, Windsor Scientific Ltd., Slough, United Kingdom), an $\mathrm{Ag} / \mathrm{AgCl} / 3 \mathrm{~mol} \mathrm{l}^{-1} \mathrm{NaCl}$ reference electrode (BAS, Model RE-1, USA), and a Pt counter electrode (BAS, MW-4130, USA) within the electrochemical cell. $\mathrm{pH}$ was measured at 25 ${ }^{\circ} \mathrm{C}$ using a $\mathrm{pH}$ meter model WTW inoLab720 equipped with a combined glass electrode (Xylem, New York, USA).

At the beginning of each experiment day, the anodic pretreatment procedure was performed by applying $+1.8 \mathrm{~V}$ potential to the BDD electrode in a $0.5 \mathrm{~mol} \mathrm{l}^{-1} \mathrm{H}_{2} \mathrm{SO}_{4}$ solution for $180 \mathrm{~s}$. After this process, the potential of $-1.8 \mathrm{~V}$ was applied to the BDD electrode for the same period and in the same solution. As a result of these steps, the BDD electrode surface acquired oxygen and hydrogenterminated properties [37]. Finally, this electrode was gently polished with a polishing pad and rinsed with deionized water before each voltammetric experiment.

Firstly, the cyclic voltammetry (CV) technique was used to elucidate the electrochemical behavior of DIF and determine the reaction kinetics on the BDD electrode in the selected supporting electrolyte. Then, the optimization of experimental parameters such as supporting electrolyte, accumulation parameters and surfactant concentration were conducted by using the SWV method in order to improve the selectivity and sensitivity of DIF analysis. The analytical performance and practical applicability of the method were also examined with the help of the same pulse technique (i.e. SWV).

The quantitative analysis of DIF with the square wave adsorptive stripping voltammetry (SW-AdSV) technique first began by immersing 
the three electrodes into voltammetric cells containing DIF, PBS ( $\mathrm{pH} 2.5$ ) and CTAB. After this step, the open-circuit potential was applied during a pre-concentration period of $30 \mathrm{~s}$ while the solution was mixed at $500 \mathrm{rpm}$. Then, the stirring was stopped and the solution was left for $5 \mathrm{~s}$ to reach equilibrium. Finally, anodic scanning was performed from $0 \mathrm{~V}$ to $+1.5 \mathrm{~V}$ by using the SWV technique. The quantitative analysis of DIF was carried out using an optimized $75 \mathrm{~Hz}$ frequency, 40 $\mathrm{mV}$ pulse amplitude, and $10 \mathrm{mV}$ step potential values with the SWV technique.

\subsection{Sample preparation}

A commercial sample of the tablet dosage from Dolphin ${ }^{\circledR}$ was supplied by a local pharmacy. According to the manufacturer's information, each film-coated tablet contains $500 \mathrm{mg}$ DIF. Ten tablets were accurately weighed and powdered in a mortar. A sufficient amount $(17 \mathrm{mg})$ of collected content was transferred into a $100 \mathrm{ml}$ calibrated dark flask and completed to the volume with ethanol. Subsequently, the bottle content was sonicated for 15 minutes to ensure complete dissolution. A certain volume of this solution $(10 \mu \mathrm{l})$ was transferred into $10 \mathrm{ml}$ electrochemical cells with 0.1 mol $1^{-1}$ PBS buffer solution (pH 2.5) and $5 \cdot 10^{-5}$ mol $1^{-1} \mathrm{CTAB}$. Then, the unknown sample analysis was calculated using the corresponding regression equation from the calibration graph obtained for standard solutions.

\section{RESULTS AND DISCUSSION}

\subsection{Electrochemical behavior of DIF on BDD electrode}

Firstly, cyclic voltammograms were recorded to obtain information concerning the electrochemical behavior of DIF. Three consecutive CVs for $100 \mu \mathrm{g} \mathrm{ml}^{-1}$ DIF between 0 and $+1.60 \mathrm{~V}$ potentials were recorded in a $0.1 \mathrm{~mol} \mathrm{l}^{-1} \mathrm{PBS}(\mathrm{pH} 2.5$ ) solution at a potential scanning rate of $100 \mathrm{mV} \mathrm{s}^{-1}$. As can be seen in Figure 2A, DIF showed a distinct anodic oxidation peak at around +1.04 on the first scan in the oxidative direction. However, no cathodic peaks were observed in reverse scanning. This phenomenon indicates that the electrochemical behavior of DIF on the BDD electrode is irreversible. On the other hand, the anodic peak intensity and sharpness of DIF decreased significantly on the $2^{\text {nd }}$ and $3^{\text {rd }}$ cycles of the scan. This phenomenon can be explained by passivation or fouling of the electrode surface. To ascertain the effect of scan rate on the oxidation peak current of $100 \mu \mathrm{g}$ $\mathrm{ml}^{-1}$ DIF, scan rate studies were performed in the range of 10 to $100 \mathrm{mV} \mathrm{s}^{-1}$ using $\mathrm{CV}$ in $0.1 \mathrm{~mol} \mathrm{l}^{-1}$ PBS at pH 2.5 (Fig. 2B). The increase in scanning rate resulted in increasing oxidation currents in DIF and its anodic peak potential positions shifted to a slightly more positive direction. The relationship between the square root scan rate $\left(v^{1 / 2}\right)$ and anodic peak current $\left(i_{\mathrm{pA}}\right)$ of DIF was linear according to the equation:

$$
\begin{gathered}
I_{\mathrm{PA}}(\mathrm{nA})=388.6 \mathrm{v}^{1 / 2}\left(\mathrm{mV} \mathrm{s}^{-1}\right)-686.3, \\
r=0.995
\end{gathered}
$$

A similar linear correlation was found between $\log I_{\mathrm{p}}$ and $\log v$ in the following equation:

$$
\begin{gathered}
\log I_{\mathrm{p}}(\mathrm{nA})=0.733 \log v\left(\mathrm{mV} \mathrm{s}^{-1}\right)+2.051, \\
r=0.997
\end{gathered}
$$

These results indicate that the electrode reactions of DIF on the BDD electrode are mainly diffusion controlled.
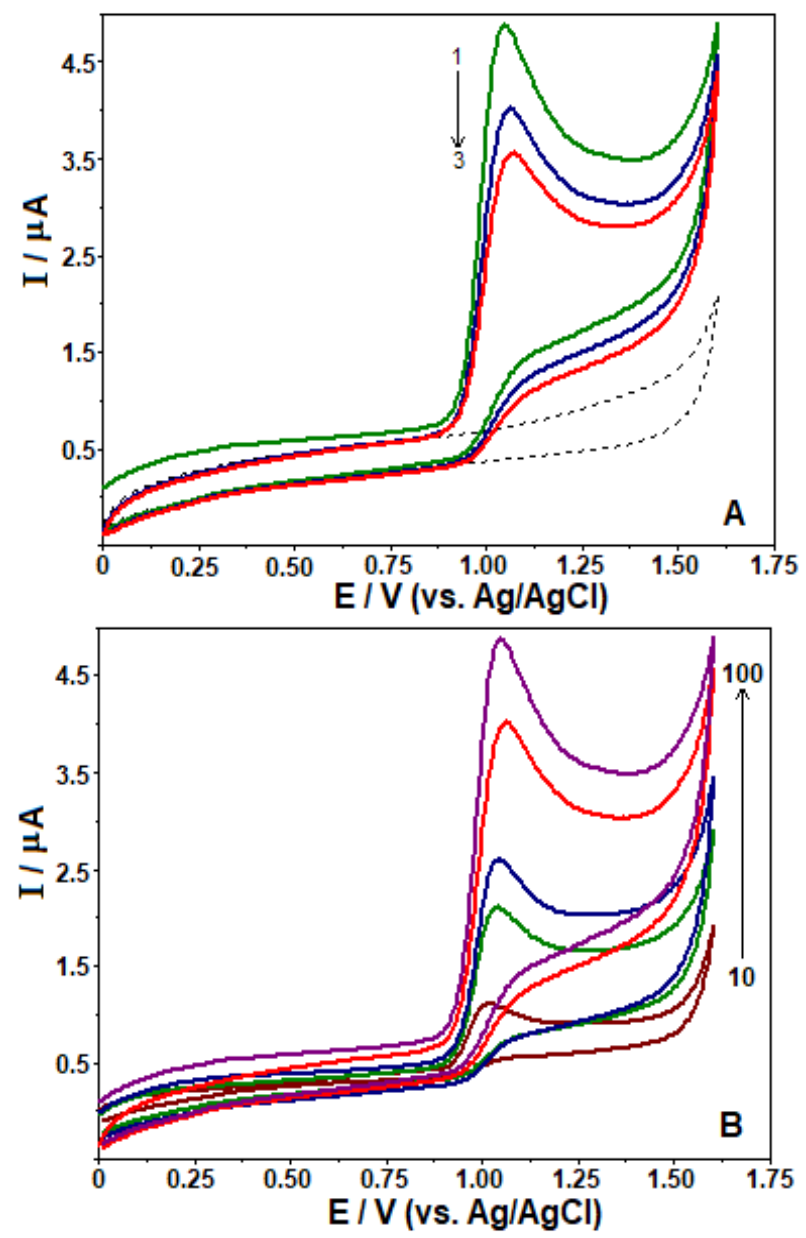

Fig. 2. Repetitive cyclic voltammograms at scan rate of $100 \mathrm{mV} \mathrm{s}^{-1}$ (A) and cyclic voltammograms at different scan rates $(10,25,50,75$ and $100 \mathrm{mV} \mathrm{s}^{-1}$ ) (B) of $100 \mu \mathrm{g} \mathrm{ml}^{-1}$ diflunisal in $0.1 \mathrm{~mol} \mathrm{l}^{-1}$ phosphate buffer solution at $\mathrm{pH} 2.5$. Dashed lines in A represent background. 
In order to ascertain the electron number $(n)$ involved in the DIF oxidation process at the BDD electrode, the $n$ value was determined by CV voltammograms using the following equation: $\alpha n=47.7 /\left(E_{\mathrm{p}}-\right.$ $\left.E_{\mathrm{p}} / 2\right)$. In this study, the value of $E_{\mathrm{p}}-E_{\mathrm{p}} / 2$ was $55 \mathrm{mV}$; thus, the value of $\alpha n$ was calculated as 0.87 . Generally, $\alpha$ (charge transfer coefficient) is assumed to be 0.5 in a totally irreversible electrode process. Hence, the $n$ value was found to be $1.74(\approx 2)$.

\subsection{Influence of electrode pretreatment procedure}

Before the voltammetric analysis of DIF, preliminary studies showed that the unpretreated BDD electrode was not be effective against passivation problems, especially at high DIF concentrations. This undesired situation prevented the unpretreated BDD electrode from producing satisfactory results in terms of sensitivity and reproducibility. To overcome this and to optimize the pretreatment procedures for the BDD electrode, the effectiveness of three different pretreatment procedures was investigated by SWV for $20 \mu \mathrm{g} \mathrm{ml}^{-1} \mathrm{DIF}$ in PBS at $\mathrm{pH} 2.5$. First, the performance of an anodic-pretreated BDD electrode was examined in voltammetric studies. Second, the performance of a cathodic-pretreated BDD electrode was investigated. Finally, anodic and cathodic pretreatment steps were applied to the BDD electrode sequentially, and the performance in voltammetric analysis was recorded. More sensitive and reproducible results were obtained in the DIF analysis when the final pretreatment procedure was applied to the BDD electrode. For this reason, this procedure was chosen as the optimum pretreatment procedure and applied to the electrode at the beginning of each experiment day. Also, a simple polishing step was performed on the electrode before analysis in order to obtain more stable voltammetric responses.

\subsection{Effect of supporting electrolyte and $p H$}

The influence of $\mathrm{pH}$ on the oxidation peak current and potential of DIF was investigated with SWV on the BDD electrode using different supporting electrolytes at various $\mathrm{pH}$ values in order to obtain the best voltammetric response for analytical purposes. In Figure 3A, the baseline-corrected $\mathrm{SW}$ voltammograms are depicted within the $\mathrm{pH}$ range 2.0-10.0 in BR buffer for $20 \mu \mathrm{g} \mathrm{ml}^{-1}$ DIF solution, with the potential ranging from $0 \mathrm{~V}$ to +1.5 V. Furthermore, in Figure 3A DIF has two oxidation peaks within the $\mathrm{pH}$ range $4.0-8.0$ at the working potential range studied. As for the position of the peak potentials, they shifted towards slightly less positive values with the change from $\mathrm{pH} 2.0$ to $\mathrm{pH}$ 6.0. The plot of $E \mathrm{p}$ versus $\mathrm{pH}$ was a straight line between $\mathrm{pH} 2.0$ and 6.0, which can be expressed by the following equation: $E_{p}(\mathrm{~V})=$ $-0.026 \mathrm{pH}+1.116$, with a linear correlation coefficient of $r=0.993$ (Fig. 3A, inset).

Also, despite the $\mathrm{pH}$ increase at $\mathrm{pH}$ values of 6.0 and above, there is no significant change in the position of the peak potential of DIF. These results can be interpreted as indicating that there is no proton transfer phenomenon accompanying electron transfer from $\mathrm{pH} 6.0$ to $\mathrm{pH} 10.0$. The effect of different supporting electrolytes on the voltammetric signals of DIF was investigated in PBS and $\mathrm{HNO}_{3}$ solutions (Fig. 3B). Since the highest and most uniform peak morphology was obtained in PBS solution, among these three different supporting electrolytes including BR, the next studies were carried out in this optimum supporting electrolyte.
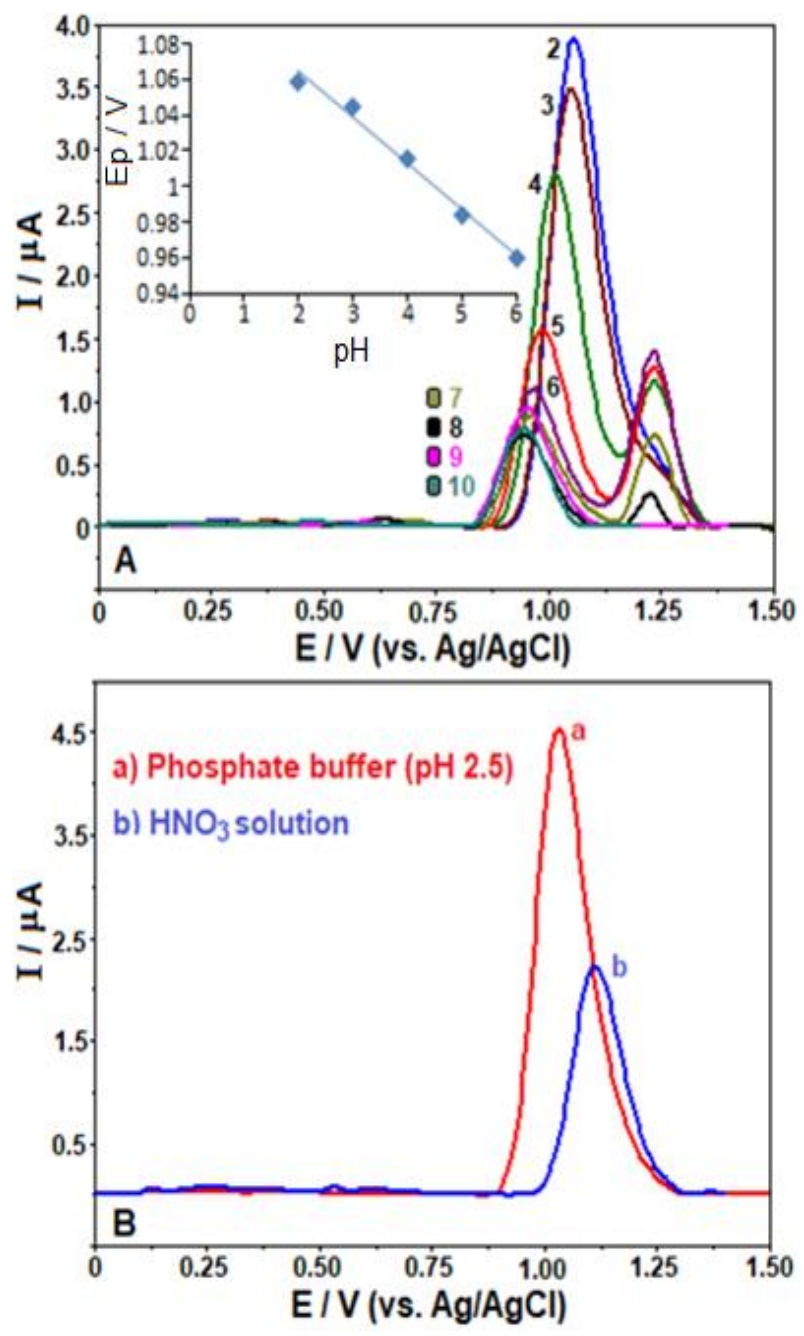

Fig. 3. SW voltammograms of $20 \mu \mathrm{g} \mathrm{ml}^{-1}$ diflunisal in $0.1 \mathrm{~mol} \mathrm{l}^{-1}$ BR buffer $\mathrm{pH} 2-10$, and at $0.1 \mathrm{~mol}^{-1}$ of various supporting electrolytes (B) at the BDD electrode. Inset in (A) depicts the plot of $E_{\mathrm{p}} \mathrm{vs}$. pH. SWV parameters: frequency, $50 \mathrm{~Hz}$; step potential, $8 \mathrm{mV}$; pulse amplitude, $30 \mathrm{mV}$. 


\subsection{Optimization of $S W V$ parameters}

Another important factor affecting the sensitivity of DIF is the optimization of pulse parameters such as frequency $(f)$, pulse amplitude $\left(\Delta E_{\mathrm{sw}}\right)$ and step potential $\left(\Delta E_{\mathrm{s}}\right)$. This optimization step was done by changing one of the pulse parameters while keeping the other two parameters constant and recording the signal obtained. First, the $f$ variable was examined in the range of $25-125 \mathrm{~Hz}$, while $\Delta E_{\mathrm{sw}}$ and $\Delta E_{\mathrm{s}}$ parameters were kept constant at $30 \mathrm{mV}$ and $8 \mathrm{mV}$, respectively. So, the best sensitivity and peak shape for this pulse variable was recorded at $75 \mathrm{~Hz}$. Next, the $\Delta E_{\mathrm{sw}}$ value was changed between 20 and $60 \mathrm{mV}$, while $\Delta E_{\mathrm{s}}$ and $f$ values were kept constant at $8 \mathrm{mV}$ and $75 \mathrm{~Hz}$, respectively. The same optimization process was carried out by keeping $f$ and $\Delta E_{\mathrm{sw}}$ constant and examining the values of $\Delta E_{\mathrm{s}}$ between 6 and $14 \mathrm{mV}$. As a result, the best SWV instrumental parameters for the BDD electrode with $10 \mu \mathrm{g} \mathrm{ml}^{-1}$ DIF in 0.1 mol $1^{-1}$ PBS pH 2.5 buffer solution (not shown) were obtained at values $f 75 \mathrm{~Hz} ; \Delta E_{\mathrm{s}} 10 \mathrm{mV}$; and $\Delta E_{\mathrm{sw}} 40 \mathrm{mV}$.

\subsection{Influence of cationic surfactant}

The role of cationic surfactant (CTAB) in improving the electrode-solution interface on the BDD electrode and its contribution to the sensitive analysis of DIF was also investigated. To investigate this effect, $100 \mu \mathrm{l}$ of $0.01 \mathrm{~mol} \mathrm{l}^{-1} \mathrm{CTAB}$ stock solution was transferred to the electrochemical cell and measurements were carried out without any accumulation step. Similar measurements were carried out for CTAB-free solutions (containing only DIF in supporting solution) and compared to the former measurements. There was no significant difference between the two measurements. However, it was observed that the sensitivity of DIF measurements significantly increased in the presence of CTAB following the accumulation step (at the open-circuit voltage for $30 \mathrm{~s}$ ). After this step, the optimization of CTAB concentration was carried out to enhance DIF sensitivity. For this purpose, CTAB concentration was enhanced from $5 \cdot 10^{-6} \mathrm{~mol} \mathrm{l}^{-1}$ to $1 \cdot 10^{-4} \mathrm{~mol} \mathrm{l}^{-1}$, keeping the DIF concentration constant at $1.0 \mu \mathrm{g} \mathrm{ml}^{-1}$ in $0.1 \mathrm{M}$ PBS solution ( $\mathrm{pH} 2.5)$. There was a significant increase in DIF oxidation signals with the addition of CTAB to the supporting electrolyte (Fig. 4). Moreover, the positions of DIF signals with CTAB added to the buffer solution shifted to slightly positive potentials. A more important observation was that the DIF signal obtained in the presence of $5 \cdot 10^{-5}$ mol $1^{-1}$ CTAB was 6.8 times more sensitive than the DIF signal without CTAB. The height of the DIF oxidation signal was unchanged despite the increase in surfactant concentration at this CTAB concentration. As a result, it was decided that DIF analysis produced more sensitive responses in the presence of $5 \cdot 10^{-5} \mathrm{~mol}^{-1} \mathrm{CTAB}$ by applying a 30 $\mathrm{s}$ accumulation step. Therefore, both the determination of the linear working range and the subsequent drug applications were performed under these optimized conditions.

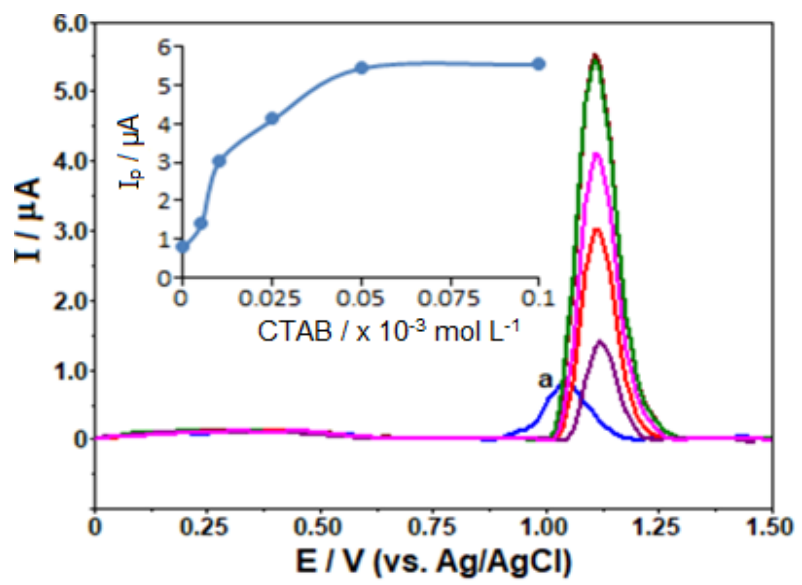

Fig. 4. SW stripping voltammograms of $1.0 \mu \mathrm{g} \mathrm{ml}^{-1}$ diflunisal in 0.1 mol $1^{-1}$ phosphate buffer ( $\left.\mathrm{pH} 2.5\right)$ solution in the presence of different CTAB concentrations $\left(5.0 \cdot 10^{-6}-1.0 \cdot 10^{-4} \mathrm{~mol}^{-1}\right)$. Blue line (a) represents the voltammogram without CTAB. Inset: plot of $i_{\mathrm{p}}$ vs. CСТАВ. Electrode, BDD; accumulation time $30 \mathrm{~s}$ at open-circuit condition. SWV parameters: frequency $75 \mathrm{~Hz}$; step potential $10 \mathrm{mV}$; pulse amplitude $40 \mathrm{mV}$.

\subsection{Analytical performance evaluation}

The performance of the developed SWV method for the BDD electrode was tested in optimized experimental and instrumental conditions. Figure 5 shows the increase in anodic current obtained as a function of the DIF standards added in the range from $0.05\left(2.0 \cdot 10^{-7}\right)$ to $2.0 \mu \mathrm{g} \mathrm{ml}\left(8.0 \cdot 10^{-6}\right.$ mol $1^{-1}$ ) with $5 \cdot 10^{-5} \mathrm{~mol} \mathrm{l}^{-1}$ CTAB. The highly linear relationship between the SW voltammograms procured in response to these successively added DIF concentrations is as follows:

$$
\begin{gathered}
I_{\mathrm{p}}(\mu \mathrm{A})=4.806 C\left(\mu \mathrm{g} \mathrm{ml}^{-1}\right)+0.148 \\
(r=0.999, n=10)
\end{gathered}
$$

where $I_{\mathrm{p}}$ is the stripping peak current, $C$ concentration, $r$ the correlation coefficient, and $n$ the number of experiments. 


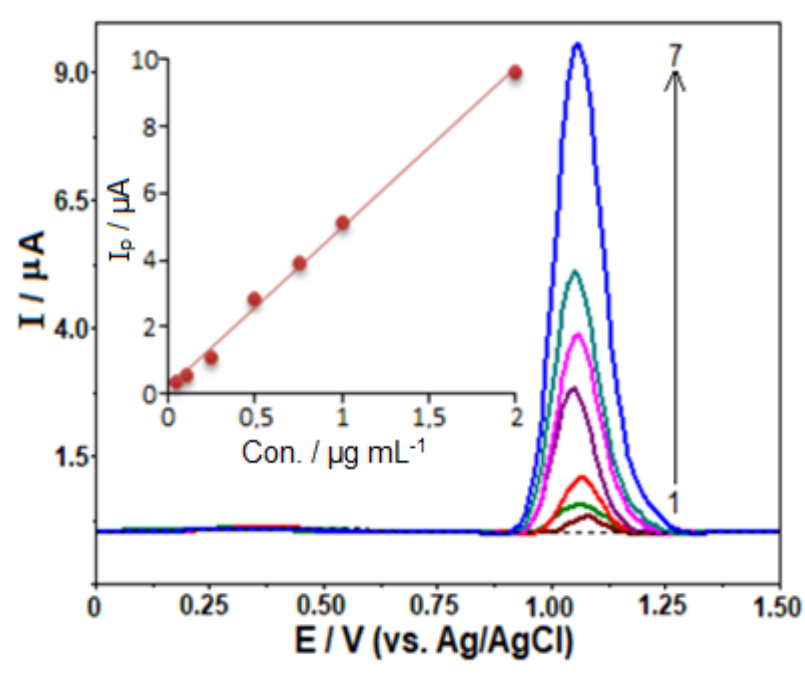

Fig. 5. SW stripping voltammograms for diflunisal levels of (1) 0.05 , (2) 0.1 , (3) 0.25 , (4) 0.5 , (5) 0.75 , (6) 1.0 and (7) $2.0 \mu \mathrm{g} \mathrm{ml}^{-1}$ in $0.1 \mathrm{~mol}^{-1}$ phosphate buffer $(\mathrm{pH} 2.5)$ solution in the presence of $5 \cdot 10^{-5} \mathrm{~mol} \mathrm{l}^{-1} \mathrm{CTAB}$. Inset depicts the corresponding calibration plot for the quantification of diflunisal. Other operating conditions as indicated in Figure 4.

The developed methodology reached the level of $0.013 \mu \mathrm{g} \mathrm{ml}^{-1}\left(5.2 \cdot 10^{-8} \mathrm{~mol} \mathrm{l}^{-1}\right) \mathrm{LOD}$ and $0.043 \mu \mathrm{g} \mathrm{ml}^{-1}\left(1.7 \cdot 10^{-7} \mathrm{~mol} \mathrm{l}^{-1}\right)$ LOQ by using a simple pretreatment procedure applied to the BDD electrode and the presence of a cationic surfactant. The LOD and LOQ values were calculated according to the $3 \mathrm{~s} / \mathrm{m}$ and $10 \mathrm{~s} / \mathrm{m}$ formulas where $s$ and $m$ are the standard deviation of ten consecutive measurements of the lowest concentration in the calibration range and the slope of the corresponding calibration curve, respectively. This LOD value proves that the sensitivity of the method is adequate, and it can be applied to real samples. In addition, the developed method has a distinctive position among other electroanalytical techniques developed for DIF analysis due to sensitivity level, speed, and simplicity of the processing procedures applied to the electrode (Table 1).

To test the precision of the method, the concentration of $0.05 \mu \mathrm{g} \mathrm{ml}^{-1}$ DIF was examined for intra-day (ten replicates) and inter-day (five days) reproducibility in the same conditions, and relative standard deviation (RSD) values were calculated as $7.79 \%$ and $9.26 \%$, respectively. These values indicate that the BDD electrode produces sufficiently reproducible results for DIF measurements.

Table 1

Comparison with published electroanalytical methods for DIF detection

\begin{tabular}{|c|c|c|c|c|c|c|}
\hline $\begin{array}{l}\text { Working } \\
\text { electrode }\end{array}$ & $\begin{array}{l}\text { Supporting } \\
\text { electrolyte }\end{array}$ & Technique & $\begin{array}{l}\text { Linear } \\
\text { range, } \mu \mathrm{M}\end{array}$ & LOD, $\mathrm{nM}$ & Analyzed samples & Ref. \\
\hline SMDE & BR pH 7.8 & $\begin{array}{l}\text { DPP, } \\
\text { DPAdSV }\end{array}$ & $\begin{array}{l}36-160 \\
16-120\end{array}$ & $\begin{array}{l}20000 \\
400\end{array}$ & tablets & {$[15]$} \\
\hline $\mathrm{MMT}-\mathrm{Ca} / \mathrm{CPE}$ & ABS pH 5.0 & SWAdAS & $0.03-0.5$ & 3.0 & tablets & [16] \\
\hline $\mathrm{BDD}$ & PBS pH 2.5 & SWV & $0.2-8.0$ & 52 & tablets & This work \\
\hline
\end{tabular}

Electrode: SMDE: static mercury drop electrode; MMT-Ca/CPE: montmorillonite-Ca-modified carbon paste electrode; BDD: boron-doped diamond electrode. Technique: DPP: differential pulse polarographic; DPAdSV: differential pulse adsorptive stripping voltammetric; SWAdAS: square-wave adsorptive anodic stripping voltammetric; SWV: square-wave voltammetric.

\subsection{Influence of some interfering species on determination of DIF}

Prior to the analyses of real samples, the selectivity of the proposed SWV protocol was also investigated in the presence of some species such as lactose, sucrose, fructose, glucose, ascorbic acid, dopamine, uric acid and ions such as $\mathrm{Ti}^{+4}, \mathrm{Fe}^{+3}$, $\mathrm{Zn}^{+2}, \mathrm{Mg}^{+2}, \mathrm{Ca}^{+2}, \mathrm{~K}^{+}, \mathrm{Na}^{+}, \mathrm{NO}_{3}{ }^{-}, \mathrm{Cl}^{-}, \mathrm{SO}_{4}{ }^{-2}$, and some agents present in pharmaceutical formulations such as starch, talc, cornstarch and magnesium stearate. This interfering effect on the DIF signal was examined at 1:1, 1:10 and 1:100 (DIF: interfering species) molar ratios in supporting electrolyte containing $1.0 \mu \mathrm{g} \mathrm{ml}^{-1}$ DIF. The signal ob- tained from the mixture of DIF and the interfering species was compared with the signals obtained from the solution only containing DIF. The maximum concentration of the foreign substance that affected the DIF signal less than $7 \%$ was described as the tolerance limit. Metal ions had no significant effect on the quantitative determination of DIF. This behavior may be due to metal ion signals being seen at negative potentials and DIF oxidation having positive potential. The effects of interfering species such as starch, talc, cornstarch, and magnesium stearate on the oxidation signal of DIF showed a negligible effect even at over 100 times concentration. Species such as lactose, sucrose, fructose, and glucose did not show a signifi- 
cant interfering effect for the quantitative determination of DIF even at 100 times the DIF concentration. However, it was not possible to analyze DIF when the concentration of dopamine and uric acid were equal to DIF and the concentration of ascorbic acid was ten times higher than DIF. In order to analyze these compounds together, either a preseparation method such as chromatography or a chemometric method should be chosen. To conclude, the proposed voltametric protocol is sufficiently selective and can perform DIF analysis in complex matrices.

\subsection{Application of the proposed method to pharmaceutical formulation}

The accuracy and practical usability of the proposed electroanalytical methodology was tested in commercially available pharmaceutical formulations by using the multiple standard addition method. Sample preparation procedures are described in detail in the experimental section. At this stage, it should be stressed that the sample was used only after a simple dilution step without any preseparation, filtering, and evaporation steps. Different volumes of standard DIF stock solution were transferred to the electrochemical cell containing the drug sample. As a result of these successive transfers, the final concentrations of DIF in the cell were adjusted to $0.25,0.5$, and $0.75 \mu \mathrm{g} \mathrm{ml}^{-1}$, respectively. Figure 6 shows overlapping voltammograms obtained from the drug sample before and after each concentration was added.

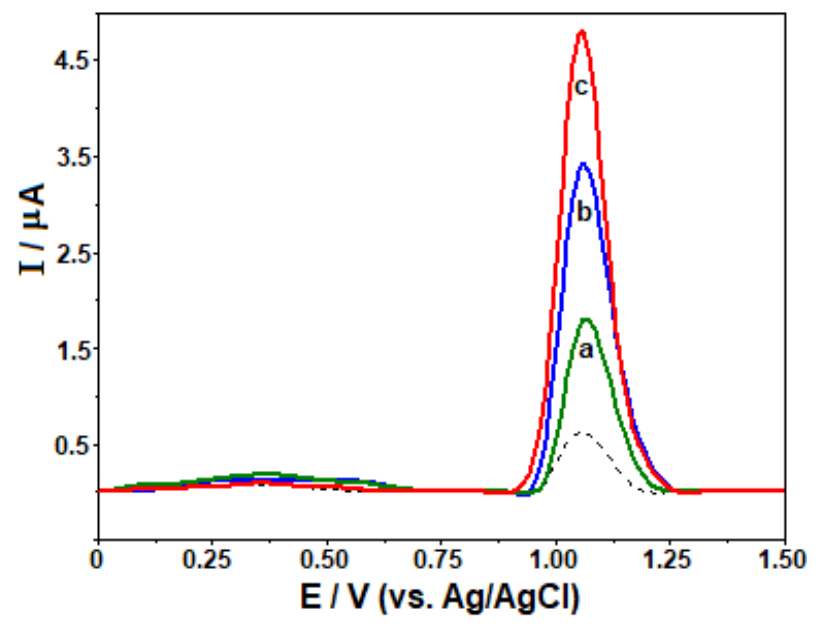

Fig. 6. SW stripping voltammograms of the diluted samples of tablet sample extracts before (dashed lines) and after standard additions of 0.25 (a), 0.50 (b) and 0.75 (c) $\mu \mathrm{g} \mathrm{ml}^{-1}$ diflunisal in $0.1 \mathrm{~mol} \mathrm{l}^{-1}$ phosphate buffer $(\mathrm{pH} 2.5)$ solution in the presence of $5 \cdot 10^{-5} \mathrm{~mol} \mathrm{l}^{-1} \mathrm{CTAB}$. Other operating conditions as indicated in Figure 4.
The peak appearing at approximately +1.07 $\mathrm{V}$ belongs to DIF oxidation, and it increased linearly with the increase in the concentration of added standards. Each Dolphin ${ }^{\circledR}$ tablet was calculated to contain an average of $480.0 \mathrm{mg}$ DIF (RSD of 4.78 $\%)$ when evaluated on the basis of these successive additions. This result also complies with the manufacturer's declaration claiming each tablet contains $500 \mathrm{mg}$ DIF. To test the validity of the proposed method, this stage was assessed with the recovery method. Satisfactory recovery values were obtained in the range from 99.3 to $108.4 \%$, indicating no notable interference in the commercial pharmaceutical formulation forms. These results proved that DIF analyses can be performed safely without significant interference in commercial drug samples.

\section{CONCLUSIONS}

In this paper, an unmodified BDD electrode was used as a sensitive electrochemical sensor for direct DIF determination in the presence of a cationic surfactant (CTAB). Electrochemical behavior and quantitative analysis of DIF were characterized by a CV technique and an SWV method, respectively. In addition to experimental parameters such as surfactant concentration and supporting electrolyte, the roles of SWV variables in improving DIF signal sensitivity were investigated and optimized. In these optimum conditions, the DIF concentration was observed to increase linearly from 0.05 to $2.0 \mu \mathrm{g} \mathrm{ml}^{-1}$ at the BDD electrode by using the SWV technique. Also, a low LOD level $(0.013 \mu \mathrm{g}$ $\mathrm{ml}^{-1}$ ) was achieved thanks to the presence of CTAB. The proposed protocol offers a good alternative to other analytical methodologies with advantages such as speed, simplicity, ease of use, economics, and reasonable sensitivity. Thanks to sufficient selectivity, the practical usability of the method was demonstrated in pharmaceutical samples with an average recovery rate of $99.8 \%$. Finally, the developed method will constitute a good reference point for electrochemical studies related to DIF to be developed with different electrodes.

Conflict of interest. On behalf of all authors, the corresponding author states that there is no conflict of interest.

\section{REFERENCES}

[1] S. Fountoulaki, F. Perdih, I. Turel, D. P. Kessissoglou, G. Psomas, Non-steroidal anti-inflammatory drug diflunisal interacting with $\mathrm{Cu}(\mathrm{II})$. Structure and biological features, J. Inorg. Biochem., 105, 1645-1655 (2011). DOI: http://doi.org/10.1016/j.jinorgbio.2011.09.004. 
[2] S. J. Barkin, Management of chronic pain. Part II, Disease-a-Month., 42, 457-507 (1996). DOI: http://doi.org/10.1016/S0011-5029(96)90013-9.

[3] R. A. Turner, J. P. Whipple, R. W. Shackleford, Diflunisal 500-750 mg versus aspirin $2600-3900 \mathrm{mg}$ in the treatment of rheumatoid arthritis, Pharmacother. $J$. Hum. Pharmacol. Drug Ther., 4, 151-157 (1984). DOI: http://doi.org/10.1002/j.1875-9114.1984.tb03341.x.

[4] K. McCormack, Non-steroidal anti-inflammatory drugs and spinal nociceptive processing, Pain., 59, 9-43 (1994). DOI: http://doi.org/10.1016/0304-3959(94)90045-0.

[5] A. A. M. Wahbi, M. M. Mabrouk, M. S. Moneeb, A. H. Kamal, Simultaneous determination of the two nonsteroidal anti-inflammatory drugs; diflunisal and naproxen in their tablets by chemometric spectrophotometry and HPLC, Pak. J. Pharm. Sci., 22, 8-17 (2009).

[6] E. S. Lianidou, P. C. Ioannou, C. K. Polydorou, C. E. Efstathiou, Synchronous scanning second derivative spectrofluorimetry for the simultaneous determination of diflunisal and salicylic acid added to serum and urine as ternary complexes with terbium and EDTA, Anal. Chim. Acta., 320, 107-114 (1996).

DOI: http://doi.org/10.1016/0003-2670(95)00517-X.

[7] H. M. Maher, Simultaneous determination of naproxen and diflunisal using synchronous luminescence spectrometry, J. Fluoresc., 18, 909-917 (2008). DOI: http://doi.org/10.1007/s10895-008-0322-5.

[8] H. M. Maher, Development and validation of a stabilityindicating HPLC-DAD method with ANN optimization for the determination of diflunisal and naproxen in pharmaceutical tablets, J. Liq. Chromatogr. Relat. Technol., 37, 634-652 (2014). DOI: http://doi.org/10.1080/10826076.2012.758134.

[9] R. A. Shaalan, T. S. Belal, Validated stability-indicating HPLC-DAD method for the simultaneous determination of diclofenac sodium and diflunisal in their combined dosage form, Sci. Pharm., 81, 713-731 (2013). DOI: http://doi.org/10.3797/scipharm.1301-24.

[10] A. Kot-Wasik, J. Dębska, A. Wasik, J. Namieśnik, Determination of non-steroidal anti-inflammatory drugs in natural waters using off-line and on-line SPE followed by LC coupled with DAD-MS, Chromatographia., 64, 13-21 (2006). DOI: http://doi.org/10.1365/s10337-006-0797-7.

[11] D. S. Patel, N. Sharma, M. C. Patel, B. N. Patel, P. S. Shrivastav, M. Sanyal, Sensitive and selective determination of diflunisal in human plasma by LC-MS, J. Chromatogr. Sci., 51, 872-882 (2013). DOI: http://doi.org/10.1093/chromsci/bms181.

[12] E. Wåhlin-Boll, B. Brantmark, A. Hanson, A. Melander, C. Nilsson, High-pressure liquid chromatographic determination of acetylsalicylic acid, salicylic acid, diflunisal, indomethacin, indoprofen and indobufen, Eur. J. Clin. Pharmacol., 20, 375-378 (1981). DOI: http://doi.org/10.1007/BF00615408.

[13] R. Milofsky, E. Bauer, Capillary electrophoresis with post-column addition of terbium and sensitized lanthanide-ion luminescence detection for the determination of diflunisal and salicylic acid, HRC $J$. High Resolut. Chromatogr., 20, 638-642 (1997). DOI: http://doi.org/10.1002/jhrc.1240201204.

[14] Y. Ding, C. D. Garcia, Determination of nonsteroidal anti-inflammatory drugs in serum by microchip capillary electrophoresis with electrochemical detection, Electroanalysis., 18, 2202-2209 (2006).

DOI: http://doi.org/10.1002/elan.200603648.

[15] F. Sayın, S. Kır, Analysis of diflunisal by electrochemical methods, J. Pharm. Biomed. Anal., 25, 153163 (2001).

DOI: http://doi.org/10.1016/S0731-7085(00)00481-7.

[16] A. M. Beltagi, Utilization of a montmorillonite-Camodified carbon paste electrode for the stripping voltammetric determination of diflunisal in its pharmaceutical formulations and human blood, J. Appl. Electrochem., 39, 2375-2384 (2009).

DOI: http://doi.org/10.1007/s10800-009-9924-0.

[17] C. Tiribilli, R. Sokolová, S. Giannarelli, M. Valášek, On reduction of the drug diflunisal in non-aqueous media, Monatshefte für Chemie., 146, 807-812 (2015). DOI: http://doi.org/10.1007/s00706-014-1390-7.

[18] B. D. Topal, S. A. Ozkan, B. Uslu, The analytical applications of square wave voltammetry on pharmaceutical analysis, Open Chem. Biomed. Methods J., 3, 56-73 (2011). DOI: http://doi.org/10.2174/1875038901003010056.

[19] V. Mirceski, R. Gulaboski, M. Lovric, I. Bogeski, R. Kappl, M. Hoth, Square-wave voltammetry: A review on the recent progress, Electroanalysis., 25, 2411-2422 (2013). DOI: http://doi.org/10.1002/elan.201300369.

[20] O. I. Lipskikh, E. I. Korotkova, Y. P. Khristunova, J. Barek, B. Kratochvil, Electrochimica Acta Sensors for voltammetric determination of food azo dyes - A critical review, Electrochim. Acta., 260, 974-985 (2018). DOI: http://doi.org/10.1016/j.electacta.2017.12.027.

[21] F. Scholz, Voltammetric techniques of analysis: the essentials, ChemTexts., 1, 1-24 (2015). DOI: http://doi.org/10.1007/s40828-015-0016-y.

[22] J. Xu, Y. Wang, S. Hu, Nanocomposites of graphene and graphene oxides: Synthesis, molecular functionalization and application in electrochemical sensors and biosensors. A review, Microchim. Acta., (2016). DOI: http://doi.org/10.1007/s00604-016-2007-0.

[23] V. Mirčeski, R. Gulaboski, Recent advances in squarewave voltammetry: A review, Maced. J. Chem. Chem. Eng., 33, 1-12 (2014).

DOI:http://doi.org/http://dx.doi.org/10.20450/mjcce.2014.5 15

[24] M. Hanko, L. Švorc, A. Planková, P. Mikuš, Novel electrochemical strategy for determination of 6-mercaptopurine using anodically pretreated boron-doped diamond electrode, J. Electroanal. Chem., 840, 295-304 (2019). DOI: http://doi.org/10.1016/j.jelechem.2019.03.067.

[25] L. Švorc, K. Kalcher, Modification-free electrochemical approach for sensitive monitoring of purine DNA bases: Simultaneous determination of guanine and adenine in biological samples using boron-doped diamond electrode, Sensors Actuators, B Chem., 194, 332-342 (2014). DOI: http://doi.org/10.1016/j.snb.2013.12.104.

[26] S. Allahverdiyeva, P. Talay Pınar, E. Keskin, O. Yunusoğlu, Y. Yardım, Z. Şentürk, Adsorptive stripping voltammetric determination of higenamine on a borondoped diamond electrode improved by the use of an anionic surfactant, Sensors Actuators B. Chem., 303, 127174 (2020). DOI: http://doi.org/10.1016/j.snb.2019.127174. 
[27] L. Švorc, K. Borovská, K. Cinková, D. M. Stanković, A. Planková, Advanced electrochemical platform for determination of cytostatic drug flutamide in various matrices using a boron-doped diamond electrode, Electrochim. Acta., 251, 621-630 (2017). DOI: http://doi.org/10.1016/j.electacta.2017.08.077.

[28] D. F. Pereira, E. R. Santana, J. V. Piovesan, A. Spinelli, A novel electrochemical strategy for determination of vitamin $\mathrm{B} 12$ by $\mathrm{Co}(\mathrm{I} / \mathrm{II})$ redox pair monitoring with boron-doped diamond electrode, Diam. Relat. Mater., 105, 107793 (2020).

DOI: http://doi.org/10.1016/j.diamond.2020.107793.

[29] P. Samiec, L. Švorc, D. M. Stanković, M. Vojs, M. Marton, Z. Navrátilová, Mercury-free and modificationfree electroanalytical approach towards bromazepam and alprazolam sensing: A facile and efficient assay for their quantification in pharmaceuticals using borondoped diamond electrodes, Sensors Actuators, B Chem., 245, 963-971 (2017).

DOI: http://doi.org/10.1016/j.snb.2017.02.023.

[30] F. Dönmez, Y. Yardım, Z. Şentürk, Electroanalytical determination of enrofloxacin based on the enhancement effect of the anionic surfactant at anodically pretreated boron-doped diamond electrode, Diam. Relat. Mater., 84, 95-102 (2018).

DOI: http://doi.org/10.1016/j.diamond.2018.03.013.

[31] L. Švorc, J. Sochr, M. Rievaj, P. Tomčík, D. Bustin, Voltammetric determination of penicillin $\mathrm{V}$ in pharmaceutical formulations and human urine using a boron-doped diamond electrode, Bioelectrochemistry., 88, 36-41 (2012).

DOI: http://doi.org/10.1016/j.bioelechem.2012.04.004.
[32] R. Trouillon, Y. Einaga, M. A. M. Gijs, Cathodic pretreatment improves the resistance of boron-doped diamond electrodes to dopamine fouling, Electrochem. Commun., 47, 92-95 (2014). DOI: http://doi.org/10.1016/j.elecom.2014.07.028.

[33] M. Mishra, P. Muthuprasanna, K. Surya, P. Sobhita, I. A. Satish, I. S. Chandiran, G. Arunachalam, S. Shalini, Basics and potential applications of surfactants - A review, Int. J. PharmTech Res., 1, 1354-1365 (2009).

[34] J. R. Kirchhoff, E. Deutsch, W. R. Heineman, Factors influencing electroanalytical measurements in aqueous surfactant media, Anal. Lett., 22, 1323-1340 (1989). DOI: http://doi.org/10.1080/00032718908051408.

[35] S. Allahverdiyeva, E. Keskin, P. Talay Pınar, Y. Yardım, Z. Şentürk, First electroanalytical methodology for the determination of hordenine in dietary supplements using a boron-doped, Electroanalysis., 31, 2283-2289 (2019). DOI: http://doi.org/10.1002/elan.201900365.

[36] A. A. Abdullah, Y. Yardım, Z. Sentürk, The performance of cathodically pretreated boron-doped diamond electrode in cationic surfactant media for enhancing the adsorptive stripping voltammetric determination of catechol-containing flavonoid quercetin in apple juice, Talanta., 187, 156-164 (2018).

DOI: http://doi.org/10.1016/j.talanta.2018.05.016.

[37] B. C. Lourencao, R. F. Brocenschi, R. A. Medeiros, O. Fatibello-Filho, R. C. Rocha-Filho, Analytical applications of electrochemically pretreated boron-doped diamond electrodes, ChemElectroChem., 7, 1291-1311 (2020). DOI: http://doi.org/10.1002/celc.202000050. 